\title{
VARIABILITY IN ISOLATES OF Puccinia polysora IN BRAZIL
}

\author{
CARLOS R. CASELA \& ALEXANDRE S. FERREIRA
}

\author{
Embrapa Milho e Sorgo, Cx. Postal 151, CEP 35701-970, Sete Lagoas, MG, fax (31) 3779-1088, \\ e-mail: casela@cnpms.embrapa.br
}

(Accepted for publication on 26/02/2002)

Corresponding author: Carlos R. Casela

CASELA, C. R. \& FERREIRA, A. S. Variability in isolates of Puccinia polysora in Brazil. Fitopatologia Brasileira 27:414-416. 2002.

\begin{abstract}
The main objective of this work was to evaluate the variability of the southern rust pathogen Puccinia polysora in Brazil, based on its virulence on a set of maize (Zea mays) cultivars. Sixty single pustule isolates, from different areas of occurrence of southern rust, were evaluated for their virulence to 50 maize experimental hybrids. Six cultivars showed a clear distinction between susceptible and resistant reaction, and were used to

characterize the variability of the pathogen. Seventeen virulence patterns were identified among the 60 isolates tested. The most frequent virulence patterns identified, were observed in all locations of sampling, which suggests the absence of geographical differentiation among prevalent populations of $P$. polysora in Brazil.

Additional keywords: Southern rust, virulence.

\section{RESUMO \\ Variabilidade em isolados de Puccinia polysora no Brasil}

O presente trabalho teve por objetivo avaliar a variabilidade de Puccinia polysora, agente causal da ferrugem polissora, com base na sua virulência em cultivares de milho (Zea mays). Foram avaliados 60 isolados monopustulares, coletados em diferentes áreas de ocorrência da doença, os quais foram inoculados em 50 híbridos experimentais de milho. Seis cultivares permitiram uma clara distinção entre a reação de

resistência e a de suscetibilidade e foram utilizados para a caracterização dos isolados. Dezessete padrões de virulência foram observados com base nas reações diferenciais e os padrões de virulência mais frequentes foram observados em todos os locais amostrados, indicando uma possível ausência de diferenciação geográfica entre as populações de $P$. polysora prevalescentes no Brasil.
\end{abstract}

Southern rust, caused by Puccinia polysora Underw., has become a major disease of maize (Zea mays L.) in Brazil. The disease is capable of reducing yield on susceptible genotypes under favorable environmental conditions, characterized by temperatures of $23-28^{\circ} \mathrm{C}$ and high relative humidity (Melching, 1975). Damage caused by the disease includes reduction of vigor, grain size, and lodging (Leonard, 1974). Yield losses were reported in Brazil as variable from 18 to $56 \%$ under experimental conditions (von Pinho, 1998). Teliospores of the pathogen are rare in nature and are not known to germinate. Urediniospores are both the primary and secondary inoculum, and no alternate host for $P$. polysora has been found (Ullstrup, 1977; Shurtlef, 1986). Genetic resistance is the most effective and environmentally sound way to control the disease. A hypersensitive type of resistance has been identified which is very effective in preventing yield losses and, essentially, eliminates the secondary spread of the inoculum (Melching, 1975). Unfortunately, this single gene form of resistance has been of limited use due to the occurrence of a high variability of the pathogen in nature (Ryland \& Storey, 1955; Robert, 1962; Ullstrup, 1965; Melching, 1975; Yeh, 1986). Races of wider virulence range can be selected in nature and become prevalent in the pathogen population and cause severe epidemics. The main objective of this work was to evaluate the existence of variability among isolates of P. polysora, collected from different areas of occurrence of southern rust, based on the reaction of maize experimental hybrids, as a preliminary evaluation of the existence of races of this pathogen in Brazil.

A total of fifty experimental hybrids were evaluated in this study. These genotypes were components of the 1999 and 2000 National Experimental Hybrids Trials of Embrapa Maize and Sorghum Research Center and were chosen based on preliminary observation of their reactions to southern rust in maize field plots. Isolates of $P$. polysora were obtained in 1999 and 2000 from susceptible maize genotypes in experimental hybrid performance tests. Isolates in 1999 were collected in Goianésia (GO), Jardinópolis and Guaíra (SP), and Sete Lagoas (MG), whereas in 2000, collections were obtained from Goianésia (GO), Guaíra (SP), Sete Lagoas, Paracatú, Janaúba (MG) and from Cruz das Almas (BA). Urediniospores from each sample were transferred, with a sterile spatula, to seedling leaves of a susceptible genotype, previously wet with a Tween 80 solution ( 2 drops/l). Inoculated plants were then incubated in a dew chamber overnight at a temperature of $25-30{ }^{\circ} \mathrm{C}$ and $100 \%$ relative humidity and then 
returned to benches in the greenhouse under a plastic cap to prevent cross contamination. Two weeks after inoculation, urediniospores from a single isolated pustule were collected from each sample and transferred to the same susceptible genotype as previously described. This procedure was repeated three times or until pustules of a uniform size were obtained, which was considered to indicate that when the isolate was pure. Urediniospores of each single-pustule isolate were then maintained and increased for inoculations through successive transfers onto the same susceptible genotype.

For the determination of reaction type, urediniospores from each single-pustule isolate were collected with a sterile spatula, suspended in a Tween 80 solution and atomized onto maize genotypes. In all inoculations the spore concentration was standardized to $10^{4}$ urediniospores $/ \mathrm{ml}$. Maize hybrids were planted in a split-plot arrangement using a randomized complete block design, with isolates as whole plots and maize genotypes as sub-plots. Due to limitation of space in the greenhouse, five isolates were inoculated onto ten maize hybrids at a time. After inoculated, plants were incubated as previously described. The infection type was scored 15 days after inoculation, according to Robert (1962):

Resistant $-\mathrm{R}^{0}=$ no evidence of reaction on hosts; $\mathrm{R}^{1}=$ chlorotic to necrotic flecks or small lesions but no sori formed; $\mathrm{R}^{2}=$ small sori formed with very few spores.

Susceptible $-\mathrm{S}=$ sori erupting from leaf tissues, with or without chlorosis or yellowing, and containing moderate to many spores.

Intermediate $-\mathrm{X}=$ mixed reaction showing type $\mathrm{S}$ combining with $\mathrm{R}^{1}$ or $\mathrm{R}^{2}$ type or both.

Only nine hybrids were resistant to at least one isolate of $P$. polysora. From these genotypes, six showed a clear distinction between susceptible and resistant reaction, and were used to characterize isolates of the pathogen. For the identification of virulence patterns, isolates were numbered according to a binary system as proposed by Habgood (1970). In this system maize hybrids were arranged in a fixed order and susceptible reactions were represented by the formula $2^{\mathrm{n}}$, where $\underline{n}$ is a specific weight attributed to the each genotype as follows: $\mathrm{EH} 01=2^{0} ; \mathrm{EH} 02=2^{1} ; \mathrm{EH} 03=2^{2} ; \mathrm{EH} 04=2^{3}$; $\mathrm{EH} 05=2^{4} ; \mathrm{EH} 06=2^{5}$. Isolates were identified according to the total weight of susceptible reactions. For example, an isolate virulent on EH01, EH02, and EH05, would be identified as virulence pattern 19.

Seventeen virulence patterns were identified based on the reaction of the six experimental hybrids used as differentials. The more frequent virulence patterns identified, among the 60 isolates of $P$. polysora, were 05,20 , and 04 (Table 1). Virulence pattern 20 had the widest distribution, being detected in all locations. These results suggest the absence of geographical differentiation among prevalent populations of $P$. polysora in Brazil. This hypothesis is reinforced by the fact that virulence to each experimental hybrid was widely distributed among the locations sampled
TABLE 1 - Virulence patterns and distribution of Puccinia polysora isolates collected in six locations in 1999 and 2000

\begin{tabular}{cccc}
\hline \hline Virulence & \multicolumn{3}{c}{ Year/No. of Isolates (Distribution) } \\
\cline { 2 - 4 } Pattern $^{1}$ & $\mathbf{1 9 9 9}$ & $\mathbf{2 0 0 0}$ & Total \\
\hline 00 & $02(\mathrm{Gu})^{2}$ & - & 02 \\
04 & $02(\mathrm{SL}, \mathrm{Gu})$ & $07(\mathrm{SL}, \mathrm{Pa}, \mathrm{Ja}, \mathrm{CA}, \mathrm{Gu})$ & 09 \\
05 & - & $10(\mathrm{SL}, \mathrm{Pa}, \mathrm{Gu}, \mathrm{Go})$ & 10 \\
06 & $01(\mathrm{Gu})$ & - & 01 \\
08 & $01(\mathrm{Go})$ & - & 01 \\
09 & $02(\mathrm{Gu})$ & - & 02 \\
10 & $01(\mathrm{Go})$ & - & 01 \\
12 & $01(\mathrm{Go})$ & - & 01 \\
14 & $03(\mathrm{SL}, \mathrm{Go})$ & $04(\mathrm{CA}, \mathrm{Ja})$ & 03 \\
16 & $01(\mathrm{SL})$ & $01(\mathrm{SL})$ & 05 \\
17 & - & 06 & 01 \\
20 & $02(\mathrm{SL}, \mathrm{Gu})$ & $07(\mathrm{SL}, \mathrm{Pa}, \mathrm{Ja}, \mathrm{CA}, \mathrm{Gu}, \mathrm{Go})$ & 09 \\
21 & - & $06(\mathrm{SL}, \mathrm{Ja}, \mathrm{Go})$ & 06 \\
23 & - & $04(\mathrm{~Pa}, \mathrm{Gu}, \mathrm{Go})$ & 04 \\
24 & $03(\mathrm{SL}, \mathrm{Gu})$ & - & 03 \\
25 & $01(\mathrm{Gu})$ & - & 01 \\
29 & - & $01(\mathrm{Go})$ & 01 \\
Total & 20 & 40 & 60 \\
\hline 1/ Binary system, as proposed by Habgood (1970) \\
${ }^{2 /}$ SL = Sete Lagoas; Pa = Paracatú; Ja = Janaúba; CA = Cruz das Almas; Gu \\
= Guaíra; Go = Goianésia. &
\end{tabular}

(data not shown). A more intensive analysis, using a larger number of isolates, single gene differentials and/or molecular markers, is needed to confirm this hypothesis, as it has implications on the development of gene deployment strategies to control this disease in Brazil.

The identification of different virulence phenotypes of $P$. polysora, supports the hypothesis of the existence of variability in the population of this pathogen in Brazil, and is in agreement with previous reports (Ryland \& Storey, 1955; Robert, 1962; Ullstrup, 1965; Melching, 1975; Yeh, 1986). The high susceptibility of the majority of hybrids evaluated in this work, and the fact that no hybrid was resistant to all isolates are indications that the utilization of the hypersensitive type of resistance will be of low efficiency as a short term strategy to manage southern rust populations in Brazil. Research efforts of Embrapa Maize and Sorghum Research Center have, therefore, been directed, for the moment, at the identification and characterization of maize genotypes with quantitative resistance to $P$. polysora. Although this type of resistance has not been studied thoroughly in the pathosystem maize-P. polysora, it has been selected and widely deployed (Ullstrup, 1977; Kim, 1993). It is credited with stabilizing the incidence of southern rust at levels of low economic losses (Hooker, 1985; Renfro, 1998). This resistance was responsible for the control of southern rust in Africa, in a situation where vertical resistance had failed to provide adequate control (Robinson, 1976). Considering, however, the high incidence and severity of southern rust, it is advisable not to rely only on this type of resistance for the control of the disease in Brazil. It is, therefore, important, as a long-term strategy, to intensify 
research on the identification and selection on maize genotypes with the hypersensitive type of resistance to $P$. polysora associated with the development of strategies to increase their durability and stability. For example, the combination of maize lines with different genes for vertical resistance in the development of three-cross or double-cross hybrids, could be a possible alternative to include, in normal maize breeding programs, along with the multiline and pyramiding gene deployment strategies to manage populations of $P$. polysora in Brazil.

\section{REFERÊNCIAS BIBLIOGRÁFICAS}

HABGOOD, R.M. Designation of physiologic races of plant pathogens. Nature 227:1268-1269. 1970.

HOOKER, A.J. Corn and sorghum rusts. In: Roelfs, A.P. \& Bushnel, W R. (Eds.) The Cereal Rusts. Vol. II. Diseases, Distribution, Epidemiology, and Control. Academic Press, Inc. New York. 1985. pp. 207-236.

KIM, S.K. General resistance breeding for stresses in maize in tropics. In: Jacobs, T.H. \& Parlevliet, J.E. (Eds.) Durability of disease resistance. Kluwer Academic Publ. Dordrecht. 1993. p. 329.

LEONARD, K. J. Foliar pathogens of corn in North Carolina. Plant Disease Reporter 58: 532-534. 1974.

MELCHING, J.S. Corn rust: types, races, and destructive potential.
In: Proc. $30^{\text {th }}$ Annual Corn and Sorghum Research Conference. 1975. pp. 90-115.

RENFRO, B.L. Maize rusts. In: Casela, C.R., Renfro, B.L. \& Krattiger, A.F. (Eds.) Diagnosing Maize Diseases in Latin America. ISAAA Briefs No. 9. 1998. pp. 7-14.

ROBERT, A.L. Host ranges and races of corn rusts. Phytopathology 52: 1010-1012. 1962.

ROBINSON, R.A. Horizontal Pathosystem Management. In: Plant Pathosystems. Springer-Verlag, 1976. pp. 96-111.

RYLAND, A.K. \& STOREY, H.H. Physiological races of Puccinia polysora Underw. Nature 176:655-656. 1955.

SHURTLEF, M.C. Compendium of Corn Diseases. 3. Ed. St. Paul. The American Phytopathological Society Press. 1986.

ULLSTRUP, A.J. Inheritance and linkage of a gene determining resistance in maize to an American race of Puccinia polysora. Phytopathology 55:425-428. 1965.

ULLSTRUP, A.J. Diseases of corn. In: Sprague, G.F. (Ed.). Corn and corn improvement. 2. Ed. American Society of Agronomy. Cap. 8. 1977. pp. 391-500.

VON PINHO, R.G. Metodologia de avaliação, quantificação de danos e controle genético da resistência a Puccinia polysora Underw. e Physopella zeae (Mains) Cummins e Ramachar na cultura do milho. Tese de Doutorado. Universidade Federal de Lavras. 1998.

YEH, C.C. Studies on rusts of maize. Journal of Agricultural Research of China. 35:81-93. 1986. 